\section{Filosofisk religion}

Richard Rorty og Gianni Vattimo: Religionens fremtid. Redigeret af Santiago Zabala med efterord af Jens Viggo Nielsen., Aarbus Universitetsforlag, 2007, 157 sider, $198 \mathrm{kr}$.

Religion som vanvid er vanvid, der udspringer af irreligiøsitet.

Wittgenstein.

Dette er en på mange måder underlig bog. Underlig ved sin komposition, der består af spanieren Santiago Zabalas "Introduktion" til en tekst af Rorty samt en af Vattimo plus en samtale om religionens fremtid mellem Zabala og de to andre. Hertil kommer Jens Viggo Nielsens efterord. Jens Viggo Nielsen er oversætter og gør det meget godt. Det mærkelige er, at vi har en alenlang introduktion til et par småtekster og en småpludrende samtale, hvor der aldrig gås i dybden (eller for den sags skyld $\mathrm{i}$ bredden), hvorefter der følger et efterord, som er det absolut bedste i hele bogen. Det hele bliver ikke mindre mærkeligt af, at titlen på bogen er "Religionens fremtid", hvilket må siges at være tæt på falsk varedeklaration. For som oversætteren er inde på i sit efterord, diskuterer de tre ovennævnte i deres samtale og indlæg "først og fremmest kristendommens fremtid inden for den vestlige verdens demokratier" (s.116).

Men også det er vel at tage munden for fuld, da det som diskuteres grosso modo alene er, hvordan aspekter af kristendom ser ud i flugtlinien fra deres respektive filosofier. Man skulle ellers mene, at der var nok at tage fat på.

Inden for journalistikken er fænomenet mikrofonholderi alt andet end ukendt - jeg vil påstå, at det er lige så meget udbredt blandt filosoffer (og idehistorikere). Under alle omstændigheder leverer Zabala et fuldblods eksempel herpå i sin introduktion til Rortys og Vattimos tænkning - den såkaldte svage tænkning, hvor metafysik er forsvundet til fordel for venskabelig omgang med svage fundamenter, hvor selvbeskrivelsens permanente fornyelse er målet og hvor vi skulle befinde os i en helt ny epoke - postmoderniteten - der restløst er fortolkningens tidsalder - og så videre.

"Den foreliggende bog tager udgangspunkt i den position, at menneskebeden er gået ind i "fortolkningens tidsalder", i hvilken tænkningen er domineret af hensyn, som ikke blot hører til inden for videnskaben, filosofien eller religionen. Den nye dialogiske kultur, som Rorty og Vattimo har indviet, inviterer os til på den ene side at følge Friedrich Nietzsche, Martin Heidegger og Jacques Derrida i deres drastiske dekonstruktion af nærværsmetafysikken og på den anden side til at følge John Dewey, Benedetto Croce og Hans-Georg Gadamer i bevægelsen hinsides denne metafysik" (s.16-17, fremh. af HJS). 
Marx har en gang sagt, at filosofien lige så lidt ligger uden for virkeligheden som hovedet skulle ligge uden for kroppen, selv om det ikke ligger i maven. Hos Zabala bliver det hele imidlertid til hoved - her er ingen krop og hele hans fremstilling er en gang substantiel gammeldags fuldfed idealisme, med et virkeligt gedigent loss of problems som følge. I en verden, hvor mennesker i stor stil tager livet af hinanden som en dagligdags begivenhed i religionernes navn, hvor terrorisme og modterrorisme florerer i religionens navn og hvor - i mindre skala - politikken, også i Vesten, stadig mere føres under religiøse bannere, da får vi at vide, at Rorty og Vattimo har indviet en helt ny dialogisk kultur og tidsalder, nemlig postmoderniteten for menneskeheden.

Sjovt er det, at den tænkning, der her fremstilles på den ene side hævdes at være svag i betydningen uden faste funderinger, samtidig er en tænkning, der stort set alene med svage argumenter eller rene påstande hævder en postmodernitet med en betonstyrke, som kan få tidligere faste fundamenter til at blegne: "Det postmoderne menneske, som har udlevet afslutningen på den store, helhedsskabende syntese, produceret af den traditionelle metafysik, er i stand til at leve uden neuroser i en verden, hvor Gud ikke længere er nærværende [...]Det postmoderne menneske, som ikke længere har behov for den ekstreme, magiske forsikring leveret af ideen om Gud [...]Det postmo- derne menneske har således lært at leve uden angst $i$ den relative verden af halve sandheder. Idealet om en absolut sikkerhed, om en fuldstændig funderet viden og om en rationelt arrangeret verden, er for ham kun en forsikrende myte, som kendetegner menneskehedens tidlige stadier, dengang magtesløshed og frygt ansigt til ansigt med naturkræfterne blev den dominerende anskuelsesmåde $\mathrm{og}$ endte med, som det gamle ordsprog siger det, at skabe guderne" (s. 32-33). Amen! Dette skulle være postmodernitet, forstået som en overvindelse af modernitetens selvbedrag.

Som det så ofte sker, når postmodernitet hævdes som epokebestemmelse (og ikke som en kunstnerisk isme, f.eks. inden for arkitekturen), slæbes alle modernitetens selvbedrag med ind i postmoderniteten, der angivelig skulle være en overvindelse af moderniteten. Lad mig nævne to af modernitetens iøjnefaldende træk: 1) alt der er vigtigt $i$ det moderne for menneskene er moderne. Dette går igen i postmoderniteten: alt, der er vigtigt for menneskene i det postmoderne er postmoderne. At der kunne findes noget - f.eks. religion - der hverken er moderne eller postmoderne, men ej heller antimoderne, derimod amoderne - det glider helt ud af tankefeltet. 2) det postmoderne konstituerer sig via et privilegeret sted $i$ historien - et hidtil uset erkendelsespashøjde, hvor alle tidligere generationers selvbedrag endelig kan afsløres. Ideen om erkendelsespashøjde har 
været kronisk under moderniteten, og medvirket til dennes rethaveriske performans. Nu gentager det sig under påberåbelse af postmodernitet. Problemet her er ikke bare eller kun den problematiske tænkning omkring det postmoderne, men at man dybest set slet ikke får fat på, hvad der er ved at ske i moderniteten - nemlig en dobbeltbevægelse af på den ene side fastholdelse i modernitetens grundlag og på den anden side en gevaldig selvindskrænkning, hvor det centrale er, at det moderne på en og samme tid er vigtigt, men ikke alt.

Videre med Zabala. Han hævder, som tolkning af Rorty og Viattimo, at vi befinder os i den nye fortolkningens tidsalder, hvor det gælder: "I dag kan vi ikke længere forstå Gud som den ubevægelige grund under historien, fordi en sådan Gud ikke længere er blandt målene for viden: I stedet for at søge sandheden søger vi solidaritet, næstekærlighed og ironi" (s.35). Det sker bl.a. for "at forhindre kristendommen i, allieret med metafysikken i søgningen efter førsteprincipper at skabe rum for volden" (s.35). Her har vi et godt vidnesbyrd om en fra virkeligheden mere eller mindre selvstændiggjort "sandhed", nemlig at metafysik og kristendom, der bygger på et fundament, skaber rum for volden. Hvis man ikke vil beskæftige sig med virkeligheden, så er det altid godt, at en flok filosoffer kan bekræfte hinanden $\mathrm{i}$ en sådan tale, som i hvert fald ikke er intoxicated with reality.
At vi skal erstatte sandhed med solidaritet, næstekærlighed og ironi lyder måske smukt nok. Men det kunne være rart at få noget at vide om forholdet mellem disse tre stuerene normer, f.eks. er der slet ikke noget, som skal kvalificere solidariteten? Eller skal den bare være blind? Og hvad er egentlig forholdet mellem næstekærlighed og ironi? Kan vi udfolde en ironisk næstekærlighed? Tja - en næstekærlig ironi kunne måske gå an, men skulle vi så ikke kalde den humor?

Vi er altså ifølge Zabala og Vattimo (og måske Rorty) gået ind $i$ "fortolkningens tidsalder" hvor alt er fortolkning. Et yderst mærkeligt dogme, som har besat en del ny filosofi. Men det holder ikke. Langt fra alt er tolkning. Når jeg slår mig på en finger med en hammer og skriger: av! Eller: satans! - så er det ingen tolkning (hverken sekular eller religiøs). Når jeg spontant bliver betaget af en nyudsprungen rapsmark i begyndelsen af juni, så er betagelsen ikke nogen tolkning, lige så lidt som det er en tolkning, når det klør efter et myggestik. Hvilket ikke betyder at hammerslaget, rapsmarken eller myggestikket ikke kan gøres til genstand for tolkning, for det kan de da, men de oplevelser, jeg anfører er ikke tolkninger. Problemet med dogmet om, at alt er tolkning er bl.a. at sansningen er koblet fra, eller altid allerede underlagt forståelsen. Spontane oplevelser er sjældent tolkninger. Og selv om den rene sansning vel ikke er hyppig, så er 
sansning ikke reducerbar til forståelse - eller tolkning. At protagonisterne for tolkningsdogmet påberåber sig Wittgenstein er mig en gåde.

Hele Vattimos idé om det postmoderne hviler på dette ikke bare problematiske, men slet og ret forkerte dogme om, at alt er tolkning. Og da kan det heller ikke undre, at de grundlæggende selvbedrag og - til trods for vokabularet - rethaveriske momenter i moderniteten søvngængeragtigt vandrer lige ind $i$ postmoderniteten.

Med til pantolkningspostulatet hører påstanden om, at der grundlæggende ikke er forskel på naturvidenskab og humanvidenskab. Også her fremføres dette uden egentlig argumentation og man forbløffes over, at der slet ikke er nogen lampe der begynder at blinke for at gøre opmærksom på, at det kunne være rart med en forklaring på, at naturvidenskaberne har så stor succes med effekt og virkningskraft. Er det bare held? Altså heldige fortolkninger?

Efter, eller sammen med, disse dogmer er der enkelte spørgsmål om religion. $\mathrm{Nu}$ er det ikke religion an sich, men religion, eller kristendom i indsnævret betydning, som debatteres og altid kun for så vidt den kan passes ind i den fremførte filosofi. Det betyder bl.a., at religion ikke alene bliver en privatsag, men stort set uden fællesskab, den bliver godt nok venlig - for Gud er nu i det postmoderne ganske enkelt blevet en god ven men tillige helt tandløs og frem for alt bliver den rent intellektualistisk.
Hvad der fremstilles er ikke religionsfilosofi, men filosofisk religion. Så vidt Zabalas introduktion.

Herefter følger en klar og god artikel af Rorty: "Antiklerikalisme og ateisme", hvor han klargør, at "hverken de, som bekræfter eller de, som benægter Guds eksistens, kan plausibelt hævde, at de har beviser for deres synspunkter. At være religiøs i det moderne Vesten har ikke meget at gøre med udlægningen af specifikt observerbare fænomener" (s.51). Han får også lejlighed til at korrigere sig selv, idet han tidligere om sin egen position har brugt betegnelsen "ateisme", men nu finder det bedre at kalde den for "antiklerikalisme": "For antiklerikalisme er en politisk anskuelse, ikke en epistemologisk eller metafysisk. Ifølge denne anskuelse er kirkelige institutioner farlige for de demokratiske samfunds sundhedstilstand, på trods af alt det gode, som de gør - og på trods af al den trøst, som de skænker til den, der har behov for det, eller som er fortvivlet" (s.51-52). At kirkelige institutioner er farlige sådan uden videre er et temmelig letkøbt argument, der så følges op af en modifikation, der til gengæld ikke får lov til at slå igennem i den generelle tale om antiklerikalisme. Det hedder nemlig, at "ifølge vores opfattelse er religionen harmløs, så længe den er et privatanliggende - så længe kirkelige institutioner ikke forsøger at samle de troende om politiske budskaber, og så længe de troende og ikke troende er enige om at følge en "lev-og-lad- 
leve-politik" (s.52).

Her kunne det måske være passende, at pege på et par differentieringer: for det første er religion i Vesten et privatanliggende i den forstand, at ingen kan tvinges til at tro - det er altså frivilligt. Men det betyder jo ikke, at der ikke kan være fællesskaber omkring troen, og i den forstand er det ikke kun et privatanliggende. For det andet er der ingen nødvendig sammenhæng mellem kirkelige institutioner og trangen til at fremføre politiske budskaber og endelig for det tredje er det faktisk ofte set, at kirkelige institutioner har talt demokratiets sag (tænk f.eks. på den såkaldte befrielsesteologi i Sydamerika) - så der er ikke nogen som helst iboende sammenhæng mellem kirkelige institutioner og demokratisk farlighed.

Vattimo har bidraget med en artikel "Fortolkningens tidsalder", som Zabala i "Introduktionen" stort set har ophøjet til et uangribeligt dogme, så den skal ikke yderligere kommenteres.

Bogens misvisende titel referer til et interview - eller en samtale - som Zabala havde med Rorty og Vattimo i Paris 2002, som har fået titlen: "Hvad er religionens fremtid efter metafysikken?”. Interviewet er et godt eksempel på, at interviews aldrig er bedre end intervieweren. For i stedet for at problematisere Rortys og Vattimos påstande - eller at udvide diskussionsfeltet - er Zabala egentlig kun mikrofonholder. Rorty har et par klare meldinger. F.eks. når han hrvder, at "ideen om en dialog med islam er meningsløs [...] Med lidt held, så vil den islamiske middelklasse igangsætte en islamisk oplysning, men denne oplysning vil ikke have noget særligt at gøre med en "dialog med islam" (s.1o1). Ok, påstanden virker umiddelbart rigtig - men også her kunne Zabala have afbrudt og forlangt lidt mere differentierede udsagn, som f.eks. et svar på spørgsmålet: skal der heller ikke være nogen dialog med islam f.eks. i Europas stater, hvor der flere steder er mange muslimer af temmelig forskellig islamisk observans eller tro? Er islam bare en stor udifferentieret blok? Det mærkelige er jo her, at vi lige før har hørt fra Rorty, at kirken som institution er farlig for demokratiet, men det er en unuanceret filosofi måske ikke?

Et andet sted i samtalen har vi følgende ordveksling mellem Zabala og Rorty:

Santiago Zabala:"...Nietzsche sagde også, at "demokratiet er en naturliggørelse af kristendommen"',

Richard Rorty: "Han mente det som en fornærmelse, men det skulle tages som en kompliment".

Ellers er samtalen - som nævnt - uden bid, snarere sådan, at de tre herrer sidder og bekræfter hinanden i næsten alt.

Bogens længste og bedste bidrag er oversætteren Jens Viggo Nielsens efterord. Her samles der virkelig op og der peges på en række svagheder og problemer i Rortys og Vattimos positioner. F.eks. lyder det: "Det er 
jo rigtigt, at man ikke kan argumentere rationelt for, at Gud eksisterer (eller for den sags skyld for hans ikke-eksistens), men hvad udelukker, at man kan TRO eller HÅBE på det, man ikke kan argumentere rationelt for? Dette spørgsmål svarer hverken Rorty eller Vattimo tilfredsstillende på” (s.121, fremhævelse af JVN). Jens Viggo kender sin Kierkegaard og Sløk og det er ikke mindst herud fra, at stødet sættes ind. Han har også med gode argumenter fat i problemet om Gud som blot og bar en god ven, lige som der gås i kødet på Rortys og Vattimos udsagn om naturvidenskab som ren tolkning på linie med humanvidenskaber. Og endelig får JVN rettet op på realitetstabet hos Rorty og Vattimo vedrørende volden i verden.

Meget tyder på, at jens Viggo Nielsen kunne have skrevet en god mindre bog om religionens fremtid.

Hans-Jorgen Schanz

\section{Antiterrorismens idébistorie}

Mikekel Thorup og Morten Brander (red.): Antiterrorismens idéhistorie. Stater og vold i 500 år, Aarhus Universitetsforlag, 2007, 350 sider, $348 \mathrm{kr}$.

Krigen mod terror er ikke det enestående projekt, som både fortalere og kritikere kan give indtryk af - faktisk er terror og antiterror dybest set integrerede størrelser i den moderne stats idéhistoriske DNA.

Det fremgår med kompetent klarhed af antologien Antiterrorismens idébistorie, der går i dybden med både statslige og ikke-statslige voldsaktører de seneste 500 år, og som fra en række forskellige fagvinkler belyser, hvorledes diverse statsfjender, oprørere og kriminelle er blevet iscenesat og bekæmpet som 'terroristiske figurer', der bl.a. tjener til at definere statens retslige selvforståelse og voldsmonopol.

Antologiens redaktører, Mikkel Thorup og Morten Brænder, skriver herom: »Kategorien 'terroristiske figurer' forsøger at beskrive de idéhistoriske paralleller mellem statens karakteristik af sine modstandere, hvad enten terroristbegrebet, som ret beset er en moderne betegnelse, er blevet taget $\mathrm{i}$ anvendelse eller ej, fordi det er vores antagelse, at måden, hvorpå sådanne karakteristikker ytres, udgør en konstans i statens historie."

Med denne karakteristik er imidlertid også skabt en ultimativ kategori, hvor staten og dens aktuelle magthavere kan fiksere sine kritikere, opponenter og modstandere uden for al dialogisk og moralsk (og ofte også juridisk) rækkevidde som en art inkarneret ondskab. Bekæmpelsen heraf fordrer dermed ekstraordinære tiltag, der ofte selv balancerer foruroligende på - eller overskrider - den sædvanlige grænse for hævdvundne moralske og juridiske metoder.

I et tværfagligt helhedsperspektiv afdækker hovedparten af antologiens 